\title{
PRODUCTION AND CHARACTERIZATION OF BIOSURFACTANTS BY ISOLATES FROM LUBRICATING OIL POLLUTED SOIL
}

\author{
Munachimso Odinakachi ELEMBA ${ }^{* 1}$ Udeme Joshua Josiah IJAH $^{2}$ and Gozie Ofoegbu Jecinta Nneka ${ }^{3}$ \\ ${ }^{1,3}$ Department of Biology/Microbiology/Biotechnology, Alex Ekwueme Federal University Ndufu Alike, Ikwo (AE- \\ FUNAI), P.M.B 1010, Abakaliki, Ebonyi State, Nigeria
}

${ }^{2}$ Department of Microbiology, Federal University of Technology, P.M.B.65, Minna, Niger State, Nigeria

\begin{abstract}
The study intended to isolate, Produce and characterize biosurfactant producing isolates from spent lubricating oilpolluted soil. The isolated bacteria were identified as Acinectobacter iwoffii mpe25 and Micrococcus kristinea mpe12. Both bacteria exhibited the ability in producing biosurfactants as evidenced by blood haemolysis, oil displacement, and drop collapse and emulsification activities. After the fermentation for seven days, biosurfactant from the two bacteria was successfully extracted from the fermentation by centrifugation and purified by solvent extraction using acid precipitation method. Characterization of the biosurfactants was done by thin-layer chromatography (TLC), gas chromatography and mass spectroscopy (GC-MS), and Fourier transforms infrared (FTIR) spectroscopy. The bacteria lysed red blood cells by forming cleared transparent halos (beta haemolysis) around the colonies caused the wide diameter of oil displacement of $5.5 \mathrm{~cm}, 6.10 \mathrm{~cm}$, and high emulsification capacity of $74.5 \%$ and $65.0 \%$ respectively. The GC-MS revealed the presence of palmitic acid, 15-hydroxypentadecanoic acid, 2, 3dihydroxydodecanoic acid, sulfur-dodecyl-2-ethyl hexyl ester; the FTIR revealed important functional groups $(S=O$, $C-O-C, C=O)$ that defined the biosurfactant to be a glycolipid with a unique sulfonyl group in both biosurfactants. These led to the assigned name of sulfoglycolipid Bios-25 and disulfoglycolipid Bios-12 to the biosurfactant produced by A. iwoffii mpe 25 and M. kristinea mpe12 respectively. Due to the high emulsification capacity of these biosurfactants, it is recommended for use in bioremediation studies.
\end{abstract}

Keywords: Biosurfactant, Bacteria, Oil Displacement, Oil Polluted Soil, Production.

\section{INTRODUCTION}

When microorganisms grow on carbon sources, they produce a variety of compounds, mainly secondary metabolites. One of such prominent compounds is surface active agents (biosurfactants). Studies on biosurfactants are being intensified because of the inherent advantages and applications of the compounds. Biosurfactants are biodegradable and can be produced using inexpensive substrates; they are also very useful in environmental pollution abatement, enhanced oil recovery, food and pharmaceutical industries [1, 2, 3, and 4]. Most of the biosurfactants are glycolipids, among the glycolipids, the best known are rhamnolipids, sophorolipids and trehalolipids [5, 6, 7]. Species of Acinetobacter has been studied and found to produce surfactants for instance; A. calcoaceticus RAG-1 isolated from the Mediterranean Sea produced emulsan which is a high molecular weight heteropolysaccharide protein containing repeating trisaccharide and fatty acids which are covalently linked to the polysaccharide through o-ester and $\mathrm{N}$-acyl linkages [8, 9, and 10]. Different Acinetobacter spp produced different protein polysaccharide complexes that possess surface active properties but $A$. calcoaceticus represents an excellent candidate for production of surface active agents 
$[11,12]$. A. calcoaceticus BD4 and BD413 also produced extracellular BD4 emulsan in the production medium supplemented with ethanol (2\%). Amphipathic properties of BD4 emulsan are due to the association of an anionic hydrophilic polysaccharide with proteins. Selective digestion, deproteinization, reconstitution and chemical modification studies proved that the polysaccharide and protein fractions are essential for emulsification activity [8].

There are also reports suggesting that Acinetobacter sp. A3 produced two proteins/polypeptides of molecular masses of $26.5 \mathrm{kDa}$ and $56 \mathrm{kDa}$ when grown on crude oil as sole carbon source without production of any surface active agents [13, 12, and 14]. Recently it was reported that Micrococcus species have the ability to produce biosurfactant [4, 14]. Since there are no reports on biosurfactant production by other species and strains of Acinectobacter, this study aimed at production and characterization of biosurfactant by A.iwoffii and M. kristinae isolated from spent lubricating oil polluted soil in Minna, Nigeria.

\section{MATERIALS AND METHODS}

2.1 Collection of samples: Waste lubricating oil polluted soil samples were collected from different points in an automobile workshop in Minna, Niger State, Nigeria, into sterile sample bottles and was transported to the laboratory for the isolation of bacteria.Crude oil used was Bonny (Nigeria) Light Crude obtained from Alesa, Eleme, Port Harcourt Refinery, River State, Nigeria, while kerosene and diesel were obtained from Garma Petroleum Ltd, Minna, Niger State, Nigeria.

2.2 Isolation of bacteria: The isolation of bacteria was done using the method of Anandaraj and Thivakaran [15, 16]. Five grams of the oil polluted soil sample was inoculated in $50 \mathrm{ml}$ of $\mathrm{R} 2 \mathrm{~B}$ broth and incubated at $37^{\circ} \mathrm{C}$ for $24 \mathrm{~h}$. After incubation the medium was serially diluted; $1 \mathrm{ml}$ was transferred to sterile Petri dish and over that $20 \mathrm{ml}$ of R2A $\left(\mathrm{K}_{2} \mathrm{HPO}_{4} 0.3 \mathrm{~g}, \mathrm{MgSO}_{4} 7 \mathrm{H}_{2} \mathrm{O} 0.05 \mathrm{~g}\right.$, Soluble starch $0.5 \mathrm{~g}$, Dextrose $0.5 \mathrm{~g}$, Sodium pyruvate 0.3g,Peptone 0.25g, Casamino acid 0.5g, Agar agar (No.4 Oxoid) 15g, Distilled water 1L, pH7.2 \pm 0.2 ) was poured. The plates were then incubated at $25^{\circ} \mathrm{C}$ for $48 \mathrm{~h}$ along with controls and this was done in triplicates. After incubation, morphologically different colonies were selected and sub cultured repeatedly on R2A agar to obtain pure cultures. The pure cultures obtained were stored in nutrient agar (NA) slants and kept under refrigerated conditions $\left(4^{\circ} \mathrm{C}\right)$ for further screening.

2.3 Screening of Isolates for Biosurfactant-Production: The isolates were screened for their ability to produce biosurfactant using the following methods:

2.3.1 Haemolytic activity test: The isolates were streaked on blood agar and the plates incubated at $28^{\circ} \mathrm{C}$ for $48 \mathrm{~h}$. The plates were inspected visually for zone of clearance (haemolysis) around the colonies. Isolates that had ability to lyse red blood cell and form a clear zone around the colonies were noted as biosurfactant producers and recorded as positive (+) while those that could not form halo zones are recorded as non-biosurfactant producer (negative).

2.3.2 Drop collapsing test: Drop Collapse Assay developed by Jain [17] was adopted. Two microliters $(2 \mu 1)$ of the cell free supernatant were placed on an oil coated solid surface and the shape of this drop was noted after $1 \mathrm{~min}$. The collapsed oil drop indicated the presence of biosurfactant while culture supernatant which did not collapse the oil drop but rather gave rounded drops which appeared like air bubble was indicated as negative showing absence of biosurfactant. The experiment was set up in triplicates.

2.3.3 Oil spreading or oil displacement techniques: Oil displacement method according to Jaysree et al. [18] was used to determine the diameter of the clear zone, which occur after adding surfactant-containing solution on an oilwater interphase. In this test, $25 \mathrm{ml}$ of distilled water was added to a Petri dish which is $90 \mathrm{~mm}$ in diameter; $100 \mu 1$ of crude oil was added to the water surface, then $20 \mu$ l of cell free supernatant was placed gently on the surface of the oil in water. The diameter of the oil as displaced by the cell free supernatant and the clear zone formed were visualized under visible light and this was measured after 30 seconds.

2.3.4 Emulsification capacity (E24): Emulsification capacities of the isolates were tested using the method of Cooper and Goldenberg [19]. Two millilitres of kerosene and $2 \mathrm{ml}$ cell free supernatant obtained after the centrifugation of $18 \mathrm{~h}$ broth culture at $6000 \mathrm{~g}$ for $30 \mathrm{~min}$ was added into a test tube; the mixture was homogenized by vortexing at high speed for $2 \mathrm{~min}$ using Stuart auto vortex mixer (AE-11D, Great Britain). The homogenized mixture was allowed to stand for 
$24 \mathrm{~h}$ undisturbed. After $24 \mathrm{~h}$ the height of the stable emulsion layer and the total height of the mixture were measured using a meter rule; the values obtained were then used to calculate the emulsification index $\left(E_{24}\right)$ :

$\mathrm{E}_{24}=\frac{\text { height of emulsion layer }}{\text { total height of aqueous layer }} \times 100$

\subsection{Characterization and Identification of Biosurfactant Producing Organism}

The two bacterial isolates were characterized based on their Gram reaction and biochemical tests such as production of catalase, indole, oxidase, urease, utilisation of citrate and Carbohydrate (acid and gas production from carbohydrate), triple sugar iron agar test (TSI) (Hydrogen Sulphide Production), motility test, methyl red and Voges proskauer (MRVP) test, Spore staining and hydrolysis of macromolecules, starch and protein hydrolysis [20]. The isolates were identified by comparing their characteristics with those of known taxa using the scheme of George et al. [21]

\subsection{BIOSURFACTANT PRODUCTION}

The potential biosurfactant producing bacterial isolates were inoculated into a sterile Muller Hinton broth and incubated at $37^{\circ} \mathrm{C}$ for $12 \mathrm{~h}$; then $1 \mathrm{ml}$ of the $12 \mathrm{~h}$ old culture was transferred into $100 \mathrm{ml}$ of freshly prepared mineral salt medium containing $1 \mathrm{ml}$ of diesel oil. The mixture was incubated at $25^{\circ} \mathrm{C}$ for 7 days with shaking at 300 oscillations per minute using flask shaker (Stuart SFI, ST15 OSA, United Kingdom) [23; 24]

\subsection{BIOSURFACTANT EXTRACTION AND PURIFICATION}

Extraction of biosurfactant was done using acid precipitation method according to Ibrahim et al. [23]. In this method, the bacterial isolates were removed after 7 days of incubation by centrifugation at $6000 \mathrm{~g}$, using IEC FL 40R Centrifuge (USA) at $4^{\circ} \mathrm{C}$ for 30 minutes. The cell free supernatant was acidified with $1 \mathrm{M}$ of freshly prepared $\mathrm{H}_{2} \mathrm{SO}_{4}$ to obtain a $\mathrm{pH}$ of 2.0. The acidified cell free supernatants were then used for the extraction of the biosurfactant. To every $100 \mathrm{ml}$ of the acidified cell free supernatants, $100 \mathrm{ml}$ of mixture of Chloroform: methanol in the ratio of 2:1 (v/v) was added. The mixture was allowed to react for $30 \mathrm{sec}$, after which it was shaken vigorously until two phase separation was obtained. Then the upper layer containing majorly the reagents was decanted and the lower layer containing the biosurfactant was concentrated using a rotary evaporator (Model RE300, England). The solvent was evaporated and the left over sediment was poured into a test tube, washed thrice by centrifugation. Whitish colour sediment was obtained as the biosurfactant'.

2.7 Determination of dry weight of Biosurfactants: The initial weight of sterile Petri dish was taken, and the extracted biosurfactant was poured into the Petri dish. This was placed on the hot air oven for drying at $100^{\circ} \mathrm{C}$ for 30 minutes. After drying, the plates and contents were reweighed. The quantity of biosurfactant produced was determined by using the formula: (Weight of the Petri dish after drying -weight of the empty Petri dish).

\subsection{Characterization Of Biosurfactants}

2.8.1 Thin layer chromatography. Preliminary characterization of the biosurfactant was done by thin layer chromatography (TLC). Commercially prepared silica gel (F254) plates (G60, Merck, Darmstadt, Germany) were activated at temperature of $160^{\circ} \mathrm{C}$ using the hot air oven for $1 \mathrm{~h}$; then ten different points were located at a distance of $2 \mathrm{~cm}$ away from the base of the TLC plate; these points were labelled according to the code of the biosurfactants (that is, two points for one sample). $10 \mu \mathrm{l}$ of each test sample(biosurfactant) were placed on each specific labelled point using a capillary tube and was allowed to dry for 10min. Then it was placed inside a TLC tank flooded with an organic solvent (chloroform-methanol-water) at 70:10:0.5 (v/v/v) and covered with the lid. The test sample and solvent travelled along the TLC plates and after a while the movement stopped. The plates were removed and allowed to air dry for 10min and were viewed under a UV light (Model UVGL-15), separated spots were marked (circled), and then they were sprayed with Ninhydrin solution and Anthrone. All the developed spots retained a yellow colour of anthrone reagent indicating positive reaction for glycolipids according to [15]. The retention factor (RF) was determined using the expression: distance travelled by the test sample divided by the distance travelled by the solvent. 


\subsubsection{Gas chromatography and mass spectroscopy (GCMS)}

GCMS analysis of the biosurfactants was carried out according to the method used by Elemba et al. [24] from National Research Institute for Chemical Technology, NARICT [25]. The biosurfactant (1mg) was mixed with 5\% $\mathrm{HCl}$ - chloroform: methanol reagent $(1 \mathrm{ml})$. After the reaction was quenched with $1 \mathrm{ml}$ of distilled water, the sample was extracted with n-hexane and injected into GCMS (Model QP2010 PLUS, Shimadzu, Japan) equipped with a RTX5MS (30m $\times 0.2 \mathrm{~mm}$ ) capillary column and mass selective detector (AOC-20i) set to scan from $\mathrm{m} / \mathrm{z} 40$ to $\mathrm{m} / \mathrm{z} 800$ at scan rate of 1.2 scans per second. The oven temperature was initially programmed at $80.0^{\circ} \mathrm{C}$ for $3 \mathrm{~min}$ and then increased at the rate of $10^{\circ} \mathrm{C}$ per minute to $280.0^{\circ} \mathrm{C}$. The carrier gas was Helium at a flow rate of $1.58 \mathrm{ml} / \mathrm{min}$ and a split ratio of 50:1.0.

\subsubsection{Fourier transform infra-red (FTIR) analysis}

In order to determine the functional groups in the biosurfactants, FTIR analysis was carried out according to the method used by NARICT [25]. One milligram of the extracted biosurfactant was ground with $100 \mathrm{mg}$ of $\mathrm{KBr}$ pressed with a silver coated hand presser at $7500 \mathrm{~kg}$ for 30 seconds to obtain translucent pellets. The pellet obtained was inserted into Fourier Transform infrared Spectrophotometer (FTIR-8400S, Shimadzu, Japan) where the infrared spectra were recorded within the range of $4500-500 \mathrm{~cm}^{-1}$ wave number. All measurements consisted of 500 scans, and $\mathrm{KBr}$ pellet was used as background reference.

\subsection{STATISTICAL ANALYSIS}

The data generated were statistically analysed using one-way analysis of variance (ANOVA) of the Duncan descriptive test via the statistical package (SPSS) version 20.Statistical differences were set at ninety five per cent confidence limit $(\mathrm{p}<0.05)$.

\section{RESULTS}

From the results obtained it was observed that mpe 25 was a gram negative, non-motile rod while mpe 12 was gram positive, non-motile cocci. Both isolates were non-spore formers, had no ability to produce indole, urease and to utilize citrate, but they were able to produce Catalase and fermented glucose and fructose, mpe 25 was negative to hydrogen sulphide production and VP but was able to ferment sorbitol and D-mannose, whereas mpe12 was positive to hydrogen sulfide production, VP and fermented sucrose, maltose and galactose. Comparing these characteristics with those of known taxa of Bergeys Manual of Systemic Bacteriology, (mpe25 and mpe12 were identified as Acinetobacter iwoffii and Micrococcus kristinae respectively.

The results of the haemolytic activity, emulsification capacity, oil collapse, and oil displacement ability of the two bacterial isolates (mpe25 and mpe12) (Table 1) revealed that, of the two organisms tested, mpe25 had the highest emulsification capacity of $74.57 \%$ compared to $50.0 \%$ achieved by mpe12. The two isolates were both active in collapsing the oil. However, mpe 12 had higher ability to displace crude oil than mpe 25 with diameter of displacement of $6.1 \mathrm{~cm}$ and $5.5 \mathrm{~cm}$ respectively. Statistical analysis of the results indicated that there were significant differences $(p<0.05)$ in the oil displacement and emulsification activities of the organisms.

Table 1: Haemolytic activity, oil displacement activity, emulsification and drop collapse capacity of the two bacterial isolates

\begin{tabular}{lllll}
\hline Isolates code & $\begin{array}{l}\text { Beta( }(\boldsymbol{\beta}) \\
\text { heamolysis }\end{array}$ & $\begin{array}{l}\text { oil displacement } \\
\left(\mathrm{cm}^{2}\right)\end{array}$ & Drop collapse & $\begin{array}{l}\text { Emulsification } \\
\text { activity }\left(\% \mathrm{E}_{24}\right) \pm \mathrm{Se}\end{array}$ \\
\hline $\begin{array}{l}\text { Micrococcus } \\
\text { kristinae mpe12 }\end{array}$ & + & $6.1 \pm 0.5^{\mathrm{b}}$ & ++ & $65.00 \pm 1.04^{\mathrm{b}}$ \\
$\begin{array}{l}\text { Acinetobacter } \\
\text { iwoffii mpe25 }\end{array}$ & + & $5.5 \pm 0.7^{\mathrm{a}}$ & ++ & $74.57 \pm 4.37^{\mathrm{c}}$ \\
Tween 80 & - & $4.5 \pm 0.45^{\mathrm{e}}$ & - & $20.00 \pm 0.00^{\mathrm{a}}$
\end{tabular}

Key: $+=$ Positive; $\quad-=$ Negative; $\% \mathrm{E}_{24}=$ percentage emulsification index \pm Se=standard error; the superscript signify significant difference $(\mathrm{p}<0.05)$. 
The TLC results and the quantity of the biosurfactants produced by A. iwoffii mpe25and M. kristinae mpe12 (Table 2) revealed that, A. iwoffii mpe25 developed two spots on silica gel plates whereas M. kristinae mpe12 had only one spot; meaning that, A. iwoffii mpe25 contained more components and separated better than M. kristinae mpe12. However the quantity of biosurfactant produced by $A$. iwoffii mpe 25 was more $(1.6 \mathrm{~g} / 100 \mathrm{ml})$ than that produced by $M$. kristinae mpe12 (0.8g/100ml).

Table 2: The Rf value and the quantity of biosurfactant produced by the isolates

\begin{tabular}{|c|c|c|c|c|c|}
\hline \multirow[t]{2}{*}{ Organisms } & \multirow{2}{*}{$\begin{array}{l}\text { Biosurfactant } \\
\text { Codes }\end{array}$} & \multirow[t]{2}{*}{ No. of spots } & \multicolumn{2}{|c|}{ Rf value } & Quantity of \\
\hline & & & Lower & Upper & $\begin{array}{l}\text { Biosurfactant } \\
(\mathrm{g} / 100 \mathrm{ml})\end{array}$ \\
\hline $\begin{array}{ll}\begin{array}{l}\text { M. } \\
\text { mpe12 }\end{array} & \text { kristinae }\end{array}$ & Bios-12 & 1 & 0.56 & 0.00 & $0.8 \pm 0.12^{\mathrm{a}}$ \\
\hline A. iwoffii mpe 25 & Bios- 25 & 2 & 0.44 & 0.81 & $1.6 \pm 0.5^{\mathrm{b}}$ \\
\hline
\end{tabular}

$\pm \mathrm{Se}=$ standard error; the superscript signify significant difference $(\mathrm{p}<0.05)$.

Thirteen major peaks were revealed in the GCMS analysis of the biosurfactant designated Bios- 25 produced by A.iwoffii. Each peak represents a major compound present in Bios-25 (Table 3). The compounds present in Bios-25 are different from those in Bios-12 (Table 4) except for Octadecanoic and Hexadecanoic acid, but the presence of decanoic acid confirms it a glycolipid (Table 3). This implies that, the two biosurfactants are not the same. However, compounds in peaks 2, 5 and 8 compare favourably with those cited in the literature.

Table 3: Compounds present in the biosurfactant Bios-25

\begin{tabular}{|c|c|c|c|c|}
\hline $\begin{array}{l}\text { Peak } \\
\text { No. }\end{array}$ & $\begin{array}{l}\text { Retention } \\
\text { time (min*) }\end{array}$ & $\%$ Height & Compound name & Molecular formula $\left(\mathrm{Mw}^{* *}\right)$ \\
\hline 1 & 11.372 & 8.44 & Tetradecanoic acid & $\mathrm{C}_{14} \mathrm{H}_{30} \mathrm{O}_{4}(198)$ \\
\hline 2 & 12.254 & 6.06 & 4,6-dimethyl- & $\mathrm{C}_{14} \mathrm{H}_{30} \mathrm{O}_{2}(198)$ \\
\hline 3 & 12.816 & 11.40 & $\begin{array}{l}\text { Dimethyldodecanoic acid } \\
\text { n-pentadecanoic acid }\end{array}$ & $\mathrm{CH}_{3}(\mathrm{CH} 2)_{13} \mathrm{CH}_{3}(212)$ \\
\hline 4 & 14.165 & 11.71 & Hexadecanoic acid & $\mathrm{C}_{16} \mathrm{H}_{34} \mathrm{O}_{2}(226)$ \\
\hline 5 & 14.758 & 7.06 & $\begin{array}{l}\text { Sulphurous acid, dodecyl 2-ethylhexyl } \\
\text { ester }\end{array}$ & $\mathrm{C}_{21} \mathrm{H}_{44} \mathrm{O}_{3} \mathrm{~S}(376)$ \\
\hline 6 & 15.497 & 11.45 & 2,6,10,14-tetramethylpentadecanoate & $\mathrm{C}_{19} \mathrm{H}_{40} \mathrm{O}_{5}(268)$ \\
\hline 7 & 16.795 & 10 & Octadecanoic acid & $\mathrm{C}_{18} \mathrm{H}_{38}(254)$ \\
\hline 8 & 18.485 & 8.07 & 2,3-dihydroxydodecanoic acid & \\
\hline 9 & 22.183 & 7.46 & Heneicosane & $\mathrm{C}_{21} \mathrm{H}_{44}(296)$ \\
\hline 10 & 23.580 & 6.28 & Docosane & $\mathrm{C}_{22} \mathrm{H}_{46}(310)$ \\
\hline 11 & 25.829 & 5.02 & Tetracosanoic acid & $\mathrm{C}_{24} \mathrm{H}_{50} \mathrm{O}_{2}(338)$ \\
\hline 12 & 26.775 & 4.23 & Tetratriacontane & $\mathrm{C}_{34} \mathrm{H}_{70}(478)$ \\
\hline 13 & 27.644 & 2.82 & Triacontane & $\mathrm{C}_{30} \mathrm{H}_{62}(422)$ \\
\hline
\end{tabular}

$*=$ minutes, $* *=$ Molecular weight, $\%=$ percentage

Bios-12, eight major peaks were revealed representing major fatty acyl compounds present in Bios-12. Peaks 3, 5, and 6 consisted of fatty acyl compounds with eighteen carbons $\left(n-C_{18}\right)$ (Table 4). Additional compounds (delta (sup9)-cisoleic acid $\left({ }^{9}\right.$-cis-n- $\left.C_{18}\right)$, Pentadecanoic acid $\left(n-C_{15}\right)$ and 1,2 -Tetradecandiol) to those listed in Table 4 were also identified from the $\mathrm{m} / \mathrm{z}$ scans, associated with peak 5, 6 and 7 respectively. 
International Journal of Advances in Scientific Research and Engineering (ijasre), Vol 5 (11), November-2019

Table 4: Compounds present in the biosurfactant Bios-12

\begin{tabular}{|c|c|c|c|c|}
\hline $\begin{array}{l}\text { Peak } \\
\text { No. }\end{array}$ & $\begin{array}{l}\text { Retention } \\
\text { time(min*) }\end{array}$ & $\%$ Height & Compound name & $\begin{array}{l}\text { Molecular } \\
\text { formula }\left(\mathrm{Mw}^{* *}\right)\end{array}$ \\
\hline 1 & 8.582 & 3.54 & Azulene $_{\$ \$ \text { bicyclo[5.3.0]decapentaene }}$ & $\mathrm{C}_{10} \mathrm{H}_{8}(128)$ \\
\hline 2 & 20.517 & 16.66 & $\begin{array}{l}\text { n-Hexadecanoic acid }\left(n-C_{16}\right) \text {, palmitic acid } \\
\text { Tridecanoic acid }\end{array}$ & $\mathrm{C}_{16} \mathrm{H}_{32} \mathrm{O}_{2}(256)$ \\
\hline 3 & 22.043 & 4.38 & 13-hexyloxacyclotridec-10-en-2-one & $\mathrm{C}_{18} \mathrm{H}_{32} \mathrm{O}_{2}(280)$ \\
\hline 4 & 22.329 & 4.37 & 9-Octadecenoic(Z)-methyl ester $\$ \$$ oleic acid & $\mathrm{C}_{19} \mathrm{H}_{36} \mathrm{O}_{2}(296)$ \\
\hline 5 & 23.465 & 29.77 & Octadec-9-enoic acid & $\mathrm{C}_{18} \mathrm{H}_{34} \mathrm{O}_{2}(282)$ \\
\hline 6 & 23.697 & 21.49 & Stearic acid & $\mathrm{C}_{18} \mathrm{H}_{36} \mathrm{O}_{2}(284)$ \\
\hline 7 & 26.785 & 9.17 & 15-hydroxypentadecanoic acid & $\mathrm{C}_{15} \mathrm{H}_{30} \mathrm{O}_{3}(258)$ \\
\hline 8 & 29.073 & 10.62 & Oleoyl chloride $_{\$ \$}$ oleic acid chloride & $\mathrm{C}_{18} \mathrm{H}_{33} \mathrm{ClO}(300)$ \\
\hline
\end{tabular}

$*=$ minutes; $* *=$ molecular weight; $\$ \$=$ esterified

The IR spectrum of Bios-25 (Figure 1) revealed seven major functional groups (Table 5) in the biosurfactant of which the band at the wave number $1744.67 \mathrm{~cm}^{-1}$ indicated the presence of carbonyl $\mathrm{C}=\mathrm{O}$ ) absorption band stretching from ester indicating the presence of carboxyl group. The $\mathrm{sp}^{2} \mathrm{C}-\mathrm{H}$ stretch from aliphatic was observed at $2929.97 \mathrm{~cm}^{-1}$ and a weak asymmetric stretching peak at $1368.54 \mathrm{~cm}^{-1}$ indicating C-O-C stretching of the rhamnose. Furthermore, a weak symmetric peak at $1164.08 \mathrm{~cm}^{-1}$ representing sulfonyl $(\mathrm{S}=\mathrm{O})$ stretching indicating the presence of sulfate was observed (Table 5).

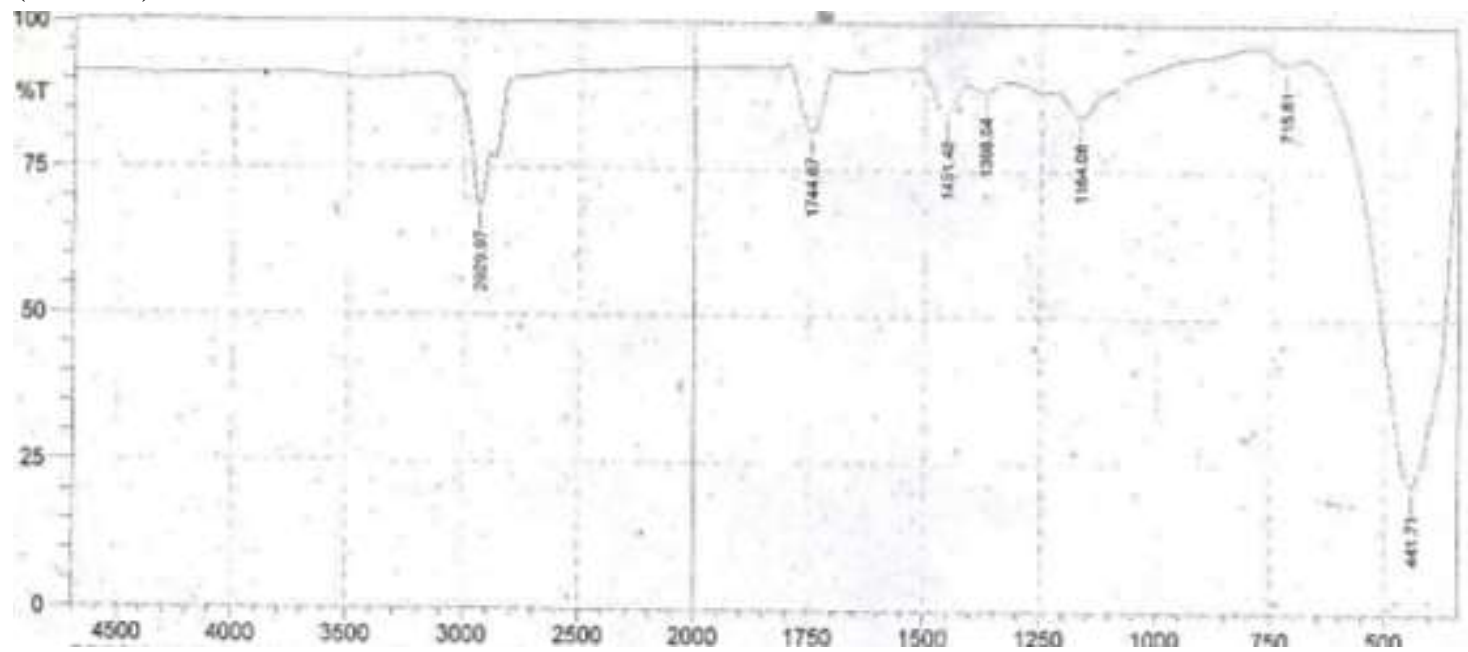

The various numbers attached to peaks are the wavelength $(\mathrm{cm})$ corresponding to each functional group Figure 1: Infrared spectra for biosurfactant Bios-25 from Acinetobacter iwoffii mpe25

Table 5: Infra-red interpretation for the biosurfactant Bios-25 from Acinetobacter iwoffii mpe25

\begin{tabular}{lll}
\hline No. & Wave No. $\left(\mathrm{cm}^{-1}\right)$ & Functional groups \\
\hline 1 & 441.71 & Stretches from C $\equiv \mathrm{C}-\mathrm{H}(\mathrm{s})$ \\
2 & 715.61 & $\mathrm{C}=\mathrm{C}-\mathrm{H}$ \\
3 & 1164.08 & $\mathrm{~S}=\mathrm{O}$ from sulfonyl \\
4 & $1368.54^{*}$ & $\mathrm{C}-\mathrm{O}-\mathrm{C}$ asymmetric stretch $(\mathrm{vs})$ \\
5 & $1451.48^{*}$ & $\mathrm{C}-\mathrm{H}$ bending from aliphatic \\
6 & $1744.67^{*}$ & $\mathrm{C}=\mathrm{O}$ stretch(v) \\
7 & $2929.97^{*}$ & $\mathrm{Sp}{ }^{2} \mathrm{C}-\mathrm{H}$ stretch from aliphatic \\
\hline
\end{tabular}

*peaks that characterized glycolipid 
The IR spectrum of the biosurfactant Bios-12 (Figure 2) revealed ten functional groups (Table 6) in the biosurfactant of which rocky band at the wave number $4333.23 \mathrm{~cm}^{-1}$ indicated the aromatic and aliphatic C-H stretch. The weak O-H bond stretching from carboxylic acid $(\mathrm{COOH})$ was observed at $3470.06 \mathrm{~cm}^{-1}$, the weak asymmetric stretch of C-O-C at $1350.22 \mathrm{~cm}^{-1}$ and anhydride ester bond of $\mathrm{C}=\mathrm{O}$ represented by sharp symmetric peak was observed at $2924.18 \mathrm{~cm}^{-1}$ (Figure 2).

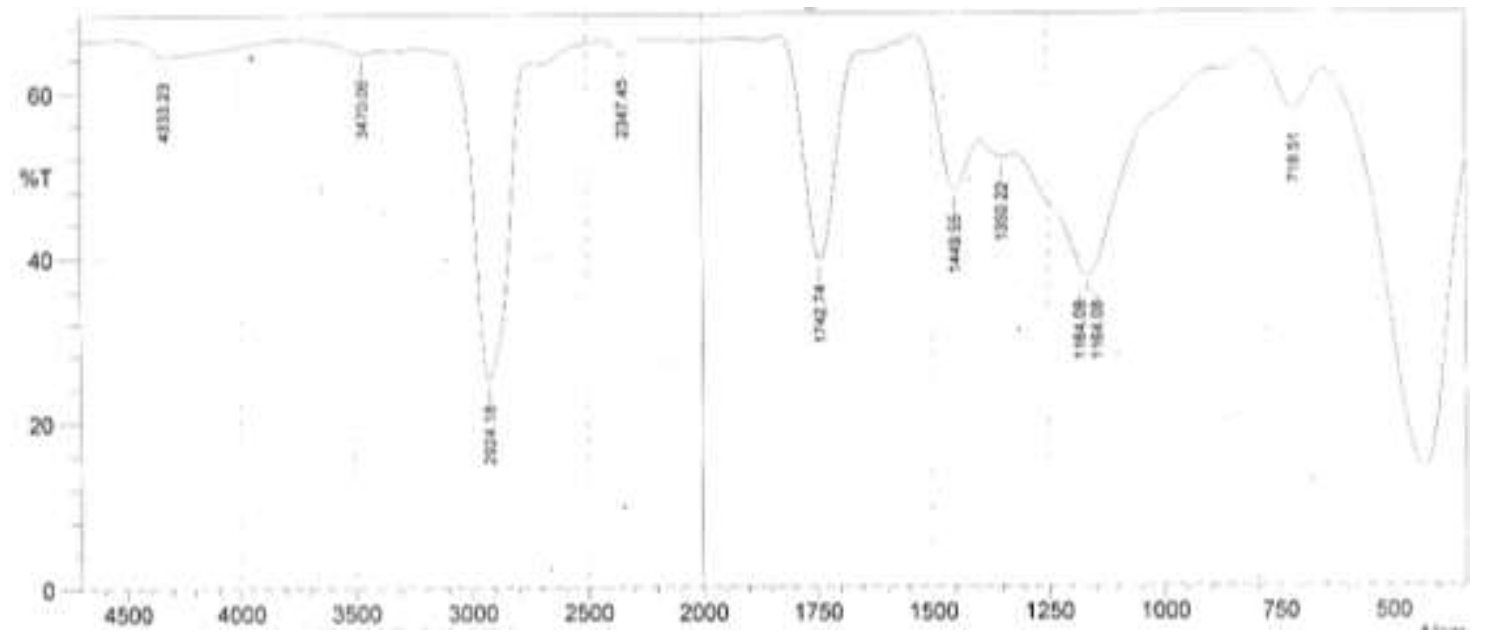

The various numbers attached to peaks are the wavelength $(\mathrm{cm})$ corresponding to each functional group

Figure 2: Infrared spectra for biosurfactant Bios-12 produced by Micrococcus kristinae mpe12

Table 6: Infra-red interpretation for the biosurfactant Bios-12 from Micrococcus kristinae mpe 12

\begin{tabular}{|c|c|c|c|c|c|}
\hline No. & $\begin{array}{l}\text { Wave } \\
\text { No. }\left(\mathrm{cm}^{-1}\right)\end{array}$ & Functional groups & Peak & $\begin{array}{l}\text { Wave } \\
\text { No. }\left(\mathrm{cm}^{-1}\right)\end{array}$ & Functional groups \\
\hline 1 & 718.51 & $\begin{array}{l}\mathrm{C} \equiv \mathrm{C}-\mathrm{H}, \mathrm{C}-\mathrm{H} \\
\text { bending }\end{array}$ & 6 & $1742.74 *$ & $\begin{array}{l}\mathrm{C}=\mathrm{O} \\
\text { (anhydride,ester) }\end{array}$ \\
\hline 2 & 1164.08 & $\mathrm{~S}=\mathrm{O}$ stretch & 7 & 2347.45 & $\begin{array}{l}\mathrm{C} \equiv \mathrm{N} \\
\text { stretch }\end{array}$ \\
\hline 3 & 1164.08 & $\mathrm{~S}=\mathrm{O}$ stretch & 8 & $2924.18 *$ & $\mathrm{C}-\mathrm{H}$ \\
\hline 4 & $1350.22 *$ & $\begin{array}{l}\mathrm{C}-\mathrm{O}-\mathrm{C}, \\
\text { symmentric and C- } \\
\mathrm{H} \text { aliphatic bending }\end{array}$ & 9 & $3470.06^{*}$ & $\begin{array}{l}\mathrm{O}-\mathrm{H}, \mathrm{COOH} \\
\text { dimmers }\end{array}$ \\
\hline 5 & $1449.55^{*}$ & $\begin{array}{l}\mathrm{C}-\mathrm{H} \quad \text { aliphatic } \\
\text { bending; } \quad \mathrm{C}=\mathrm{C} \\
\text { aromatic stretch }\end{array}$ & 10 & 4333.23 & $\begin{array}{l}\text { Aromatic and } \\
\text { aliphatic C-H stretch }\end{array}$ \\
\hline
\end{tabular}

*peaks that characterized glycolipid/rhamnolipids

\section{DISCUSSION}

The amount of biosurfactants produced by the two isolates differed (Table 2) even though they were subjected to the same condition for growth. This implies that the biosurfactant production capacity of organisms could be due to the nature and genetic makeup of the organisms. The amount of biosurfactant produced from M. kristinae mpe12 $(0.8 \mathrm{~g} / 100 \mathrm{ml})$ correlates with those obtained from M. kristinae $(8.0 \mathrm{~g} / \mathrm{l})$ by Ibrahim et al. [23]. Also 1.78 and $1.69 \mathrm{~g} / 500 \mathrm{ml}$ of biosurfactant (emulsan) was obtained from Acinetobacter calcoaceticus PAY-4 and IL-1 when grown on crude oil respectively as reported by [26] which was lower than that $(1.6 \mathrm{~g} / 100 \mathrm{ml})$ obtained in this study.

Differences in results may be attributed to the temperature of the environment; the composition and $\mathrm{pH}$ of the medium as well as the substrate used as carbon source [23, 24, and 27].

The Rf value of the biosurfactant, Bios- 25 produced by A. iwofii were 0.44 and 0.81 and compared favourably with the glycolipids from Renibacterium salmoninarium 27BN ( $\mathrm{Rf}=0.42$ and 0.83 ) studied by [28].

In this present study, the TLC and the GCMS (Table 2 and 3) revealed that Bios-25 is a glycolipid, with a fatty acid component and Sulphurous acid attached to dodecyl 2-ethylhexyl ester (that is a Sulphurous ester) which is not related 
to any biosurfactant known so far; the FTIR spectra (Figure 1, Table 5) confirmed the glycolipid nature, and the $\mathrm{S}=\mathrm{O}$ functional group proved that sulfonate was present in the compound. Following the naming scheme of Sanghoo et al. $[29 ; 30]$ and other well studied and fully characterized biosurfactants, this biosurfactant is a sulfoglycolipid and should be known as sulfoglycolipid Bios-25. This is in agreement with the report of [29].

Micrococcus species (both mutant and wild strains) have been reported to have surface active molecules consisting of phospholipid, glycolipid and neutral lipid [31, 32, 33]. The results of the study conducted by [32] revealed that Tridecanoic acid $\left(\mathrm{C}_{13}\right)$, Tetradecanoic acid $\left(\mathrm{C}_{14}\right)$, 13-Methyltetradecanoic acid (iso- $\left.\mathrm{C}_{15}\right)$, 12-ethyltetradecanoic acid (anteiso- $\left.\mathrm{C}_{15}\right)$, Hexadecanoic acid $\left(\mathrm{C}_{16}\right.$-br), Hexadecenoic acid $\left(\mathrm{C}_{16: 1}\right)$, Hexadecenoic acid $\left(\mathrm{C}_{16}\right)$, and Heptadecanoic acid $\left(\mathrm{C}_{17}\right.$-br) are major fatty acids present in lipid produced by Micrococcus luteus. All these compounds are present in the biosurfactant Bios-12 in the present study, with slight difference in the positioning of the methyl group and saturation. Bios-12 produced by Micrococcus kristinae mpe12 has two unsaturated, one branched (iso) with the methyl group attached to position 9 of the carbon chain and oleic acid attached to a chloride $\left(n-\mathrm{C}_{18}-\mathrm{Cl}\right.$ ) (Table 4; peak no 4 and 5) while that reported by the investigators had two fatty acids to which bromine is attached (Hexadecanoic acid $\left(\mathrm{C}_{16}\right.$-br) and Heptadecanoic acid $\left(\mathrm{C}_{17}\right.$-br)), two branched and one saturated fatty acid. The difference in saturation and branching may be as a result of the culture strains used. However, the entire fatty acyl component was attached to a decanoic acid and this confirms Bios-12, a glycolipid.

The FTIR (Figure 2, Table 6) revealed various bands stretch; these bands are characteristics of glycolipids and correspond with the studies of Pornsunthorntawee et al. $[34 ; 35,36]$. However, the peak at $1164.08 \mathrm{~cm}^{-1}$ had a double stretch which represented a disulfonyl $(\mathrm{S}=\mathrm{O})$ group indicating the presence of sulfates [16].

Leroy and Charles [33] reported a phospholipid with a phosphorus content (PG and PI) from Micrococcus luteus and its mutant strain mms1 and mms2, but in the present study with Micrococcus kristinae mpe12, a glycolipid consisting of two sulfonyl $(\mathrm{S}=\mathrm{O})$ group as revealed from the FTIR analysis was produced, and it was designated as disulfoglycolipid Bios-12 following the naming scheme of [29].

In conclusion this study was able to produce biosurfactants from two bacterial isolates which was characterized and named; because of inadequate financial support as a weakness the work did not venture into molecular analysis. However, the biosurfactants produced by Acinectobacter iwofii mpe 25 and Micrococcus kristinae mpe12 were identified as glycolipid with the specific name Sulfoglycolipid Bios-25 and Disulfoglycolipid Bios-12 respectively. These biosurfactants can be useful in environmental pollution abatement and other industrial processes.

\section{CONCLUSION}

Two bacteria species identified as A. iwoffii mpe25 and Micrococcus kristinea mpe12 isolated from lubricating oil contaminated site were found to be potent producers of biosurfactant. The two biosurfactants produced by the isolates were identified Based on TLC, GCMS and FTIR analyses, to be glycolipid and the presence of unique sulfonyl group in both biosurfactants led to the assigned name of sulfoglycolipid Bios-25 and disulfoglycolipid Bios-12 respectively to the biosurfactant produced. The bacterial isolates and their biosurfactants can be used for bioremediation of both crude oil and heavy metal polluted environment as revealed by their high emulsification index.

\section{ACKNOWLEDGEMENT}

All thanks to Mr Izebe, Mr Yusuf of NARICT Zaria for GCMS analysis and its interpretations, for his time for their time and maximum contributions to the success of this work. We want to thank FTIR analysis team for assisting us technically in interpreting the IR result. Authors acknowledge the immense help received from the scholars whose articles are cited and included in references of this manuscript. The authors are also grateful to authors / editors / publishers of all those articles, journals and books from where the literature for this article has been reviewed and discussed

\section{REFERENCES}

1. Rahman, P.K. and Gakpe, E. (2008). Production, characterization and application of biosurfactants. Review Biotechnology, 7(2), 360-370. 
2. Mulligan, C. N. (2009). Recent advances in environmental applications of biosurfactants. Current Opinion in Colloid and Interface Science, 14(2009), 372-378.

3. Ijah, U.J.J. and Olarinoye, R. (2012).Biosurfactant production by Bacillus strains RO7 and R28 grown on diesel. Malaysian Journal of Science,31(2), 83-90

4. Thivaharan, V. and Vytla,R.M.(2013), Production of a lipopeptide biosurfactant by a novel Bacillus sp. and its applicability to enhanced oil recovery. ISRN Microbiology13,1-8.

5. Banat, I.M., Franzetti, A., Gandolfi, I., Bestetti, I., Martinotti, G. and Marchant, R. (2010), Microbial biosurfactant production, applications and future potential. Applied Microbiology and Biotechnology, 87, 427-444.

6. Abdurrahim, A.E., Abdulrhaman, A.A., Ali, M.E., Mukhtar, E. \&Bassam, A. (2012). Removal of heavy metal contamination by biosurfactants (rhamnolipid).Journal of chemical and pharmaceutical Research,4(9), 43374341.

7. Adamu, A., Ijah, U.J.J., Riskuwa, M.L., Ismail, Y. and Ibrahim, U.B. (2015), Study on biosurfactant production by two Bacillus species. International Journal of Scientific Research in knowledge, 3(1), 013-020.

8. Rosenberg, E.and Kaplan, N.(1987). Surface active properties of Acinetobacterexopolysaccharides. In: Inouye M, editor. Bacterial outer membranes as model systems. New York: Wiley p. 311-342.

9. Gorkovenko, A., Zhang, J., Gross, R.A., Allen, A.L.and Kaplan, D.L. (1997). Bioengineering of emulsifier structure: emulsananalogs. Canadian Journal of Microbiology, 384-390.

10. Desai, J.D. and Banat, I.M. (1997). Microbial production of surfactants and their commercial potential.Microbiology and Molecular Biology Review, 61(1), 47-64.

11. Kaplan, N. and Rosenberg, E.(1986). Surface-active properties of Acinetobacterexopolysaccharides. In: Inouye M, editor. Bacterial outer membranes as model systems. New York: John Wiley and Sons, Inc. p. 311-341.

12. Surekha, K. S., Ibrahim, M. B., Prashant, K. D., Arun, G. B., and Balu, A. C. (2010).Biosurfactants, bioemulsifiers and exopolysaccharides from marine microorganisms. Biotechnology Advances, 28, 436-450 doi:10.1016/j.biotechadv.2010.02.006.

13. Phetrong, K., H-Kittikun, A., and Maneerat, S.(2008). Production and characterization of bioemulsifier from a marine bacterium, Acinetobactercalcoaceticus subsp. anitratus SM7. Songklanakarin Journal of Science and Technolology, 30(3):297-305.

14. Kapadia, S. G. and Yagnik B. N. (2013).Current Trend and Potential for Microbial Biosurfactants. Asian Journal Experimental Biological Science, 4 (1): 201-213.

15. Anandaraj, B. and Thivakaran, P.(2010), Isolation and Production of Biosurfactant Producing Organism from oil Spilled Soil. Journal of Biological Science Technology 1(3), 120-126.

16. Erum, S., Uzma, B., Jameela, A., Faiza, A. A. Maheen, W. and Maqsood A. A. (2012). Screening of surfactant producing bacterial strains isolated from soil samples of an automobile workshop. Karachi Uniersity Journal of Science.40, 31-36.

17. Jain, D., Collins-Thompson, D., Lee, H. \&Trevors, J. T. (1991). A drop-collapsing test for screening surfactantproducing microorganisms.Journal of Microbiological Methods, 13(4), 271-279.

18. Jaysree, R. D., Subham, B., Priyanka, P., Singh, T.G., Pragya, A.P.,Yekala,K. and Rajendran,N.(2011).Isolation of biosurfactant producing bacteria from environmental samples. Pharmacologyonline, 3:1427-1433.

19. Cooper,D.G.and Goldenberg,B.G. (1987). Surface active agents from two Bacillus species. Applied Environmental Microbiology, 53(2), 224-229.

20. Fawole, M.O. and Oso, B.A. (1988), Laboratory Manual of Microbiology. Ibadan (Nigeria). Spectrum Book, Limited.

21. George, M., Jalia, A.B. and Timothy, G.L. (2004).Taxonomicoutline of the Prokaryotes Bergey's Manual of Systemic Bacteriology. $2^{\text {nd }}$ edn.New York; Springer.

22. Jacobucci, D.F.C., Vasconcelos, C. K., Matsuura, A., Falconi, F.A. \&Durrant, I. R. (2001). Degradation of diesel oil by biosusrfactant producing bacterial strains.Journal of Environment Assessment and Remediation,8, 3-10.

23. Ibrahim, M.L., Ijah, U.J.J., Manga, S.B., Bilbis, L.S.and Umar, S. (2013).Production and partial characterization of biosurfactant produced by crude oil degrading bacteria.International Biodeterioration and Biodegradation81, 28-34. 
24. Elemba, O. M., Ijah, U. J.J. and Chibunna M. (2015). Isolation, characterization and Meor ability of the biosurfactant produced from Serratiamarcescens Ueo15. Global Journal of Advance Research.2(6), 962-974.

25. National Research Institute for Chemical Technology (NARICT). (2013): Method Used for GC-MS, FTIR Analysis and Detection of Fatty Acid/Lipids Profile. National Research Institute for Chemical Technology, Zaria, Nigeria.

26. Chamanronkh, P., Mazaheri, A. M., Noohi, A. and Yahyai, S. (2008), Emulsan analysis produced by locally isolated bacteria and Acinetobactercalcoaceticus RAG-1. Iran. J. Environ. Health Sci. and Eng.5(2), 101-108.

27. Peng, F., Wang, Y., Sun, F., Liu, Z., Lai, Q. and Shao, Z. (2008). A novel lipopeptide produced by a Pacific Ocean deep-sea bacterium, Rhodococcussp. TW53. Journal of Applied Microbiology, 105, 698-705.

28. Nelly, C., Borjana, T., Zdravko L., Albena, J. and Bojidar, J. (2013). Rhamnolipid biosurfactants produced by Renibacteriumsalmoninarum 27BN during growth on n-hexadecane.Journal of Biosciences, 59(2), 70-74.

29. Sanghoo, L., Kang,S., Kim,J.N. and Jung,S. (2002).Structural analysis of the novel phosphoglycolipids containing the unusual very long bifunctional acyl chain, $\alpha-\omega-13,16$-dimethyloctacosanedioate in Thermoanaerobacterethanolicus. Bulletin of the Korean Chemical Society, 23(12): 1778-1784

30. Mohammad, A. A., Hausmann, R., Lepine,F., Muller, M. M. and Deziel, E. (2011). Rhamnolipids: detection, analysis, biosynthesis and genetic regulation. Springer-verlage, 5(2):13-56.

31. De bony, J., Lopez, A., Gilleron, M., Welby, M., Laneelle, G., Rousseau, B. and Tocanne, J. F. (1989). Transverse and lateral distribution of phospholipids and glycolipids in the membrane of the bacterium Micrococcus luteus. Biochem.28, 3728-3737.

32. Pakkiri, L. S., Wolucka, B.A Lubert J. E. \&Waechter, J. C. (2004). Structural and topological studies on the lipidmediated assembly of a membrane-associated lipomannan in Micrococcus luteus.Glycobiol. 14(1), 73-81.

33. Leroy, S. P. \& Charles J. W. (2005). Dimannosyldiacylglycerol serves as a lipid anchor precursor in the assembly of the membrane-associated lipomannan in Micrococcus luteus. Glycobiology, 15(3), 291-302.

34. Pornsunthorntawee O, Arttaweeporn N, Paisanjit S, Somboonthanate P, Abe M, Rujiravanit R, andChavadej S.(2008). Isolation and comparison of biosurfactants produced by Bacillus subtilis PT2 and Pseudomonas aeruginosa SP4 for microbial surfactant-enhanced oil recovery. Biochemical Engineering Journal,42, 172-179.

35. Bondarenko, O., Rahman, P.K.S.M., Rahman, T.J., Kahru, A. and Ivask, A. (2010), Effects of rhamnolipids from Pseudomonas aeruginosaDS10-129 on luminescent bacteria: Toxicity and Modulation of Cadmium bioavailability, Microbial Ecology, 59(3), 588-600.

36. Mital,U., Jadhav,S.D.,Kalme,D. P., Tamboli,S. P., and Govindwar, R. (2011). Rhamnolipid from Pseudomonas desmolyticum NCIM-2112 and its role in the degradation of Brown 3REL. Journal of Basic Microbiology, 64120. 